FILOZOFIA

Roč. 74, 2019, č. 6

DOI: https://doi.org/10.31577/filozofia.2019.74.6.2

\title{
OTÁZKA BYTIA - HEIDEGGER VERZUS HEGEL
}

VLADIMÍR LEŠKO, Katedra filozofie a dejín filozofie, Filozofická fakulta Univerzity Pavla Jozefa Šafárika v Košiciach, Košice, SR

LEŠKO, V.: On the Question of Being - Heidegger versus Hegel

FILOZOFIA, 74, 2019, No 6, pp. $440-455$

This article investigates Heidegger's and Hegel's understanding of Being. The main focus is on Heidegger's late work and on his thinking conversation with Hegel. However, in Hegel's understanding of metaphysics there is a significant absence of the notion of being as such in its unity with the highest being, but also a desire to identify Being itself as opposed to Being of being. In Hegel's ontology Being exists always just as a Being of being. The ontological difference, which Heidegger aims to fill in all of his work, turns out to be the dead end of his thinking. Heidegger's efforts to answer the question of Being itself therefore ends in failure.

Keywords: Heidegger - Hegel - Being - being - Being of being - Question of Being - Thinking of Being

Heidegger a Hegel patria k širokej škále nemeckých filozofov, ktorí sa s výnimočnou intenzitou venovali otázke bytia, tradične chápanej ako najzložitejší ontologický problém. Obidvaja sa vo svojej dobe nazdávali, že svoje riešenie formulovali nielen metodicky, ale aj v samom výsledku, teda v jeho konečnej podobe, ktorá už nemôže byt' prekonaná. Aj preto Heidegger v polovici minulého storočia, ked’ sa pokúšal nanovo špecifikovat’ úlohu myslenia ako myslenie Bytia (Heidegger 1976c, 317; Heidegger 2000, 9), venoval najvýznamnejšiu pozornost' Hegelovi. ${ }^{1}$ Doteraz však nie je dostatočne preskúmaná miera Hegelovho vplyvu na konštituovanie Heideggerovho riešenia problému myslenia Bytia (pozri napr. Capobianco 2010, 6 a n.; de Boer 2000, 197 a n.). $\mathrm{V}$ predloženej štúdii sa preto pokúsim tomuto problému venovat' pozornost' a prezentovat' to najdôležitejšie, $\mathrm{k}$ čomu som sa doteraz prepracoval vo svojich historicko-filozofických skúmaniach (pozri Leško - Stojka a kol. 2016; Leško - Sobotka a kol. 2017; Leško - Mayerová a kol. 2018).

\footnotetext{
${ }^{1} \mathrm{~V}$ stati budem striktne rozlišovat' písanie termínu bytie $\mathrm{v}$ Heideggerovom rozlíšení s malým písmenom vo význame „bytie jestvujúcna“ a s vel'kým písmenom, ked’ ide o „Bytie samo“, teda bez vzt’ahu bytia k jestvujúcnu.
} 


\section{Heideggerova dilema či paradox?}

Dnes už takmer učebnicová poučka znie, že Heidegger zanechal vo filozofii 20. storočia nezmazatel'nú stopu svojím spisom Bytie a čas (1927), aj ked' ostala nedokončená a svojím obsahom nezodpovedala pôvodnému zámeru autora. Napriek tomu vel'mi významne pôsobila na rozvoj fenomenologickej, hermeneutickej a existencialistickej filozofie, a to nie iba v Nemecku, ale v celej európskej filozofii. Práve jej recepcia spôsobila najväčšie problémy. A to najmä pre zhustenie textu, ktorý vznikal pod silným časovým tlakom na jeho tvorcu $\mathrm{v}$ súvislosti s potrebou obsadit' profesorské miesto v Marburgu (pozri Gadamer 2008, 64 a n.), ako aj pre pomerne zložitú vnútornú štruktúru a nel'ahko zrozumitel'ný Heideggerov nový filozofický slovník. Preto sa rôzne interpretácie Bytia a času presúvali väčšmi podl’a intencií interpretátora, než aby sledovali vlastnú intenciu autora. Týmto spôsobom sa rozšrírila aj verzia, podla ktorej toto dielo patrilo do okruhu dobovo vel'mi citlivo vnímaných filozoficko-antropologických traktátov. Najvýraznejšie sa o takéto chápanie zaslúžil J.-P. Sartre svojou prácou Bytie a ničota (Sartre 2006, 14 a n.; pozri tiež Lévy 2003, 371 - 400; Sivák 2005, 311 a n.), ale najmä svojou krátkou esejou Existencializmus je humanizmus (Sartre 1997, 16).

Heidegger pri formulácii vlastnej témy diela Bytie a čas píše, že mu ide o otázku zmyslu bytia. Túto formuláciu však vtedajšie filozofické publikum, ktoré sa angažovalo $\mathrm{v}$ problémoch Lebensphilosophie, pochopilo síce mylne, ale $\mathrm{v}$ danej dobe presvedčivo, ako otázku o zmysle života. Myšlienky nenesú vinu za to, ako s nimi l'udia naložia, a je na l'ud'och, aby sa vyrovnali s dôsledkami svojho myslenia. Heideggerovi tak nezostalo iné, než sa dlhé roky bránit' obvineniam z existencializmu a dokladat', že jeho záujem tkvie takmer výlučne len v ontológii. Zarad'ovanie medzi existencialistov Heidegger pokladal za nehorázny omyl, musel sa ustavične vyrovnávat's tým, že aj jeho najbližší kolegovia opakovane narážali na aspekty existenciálne ladenej filozofickej antropológie, s ktorými sa môžeme v hojnom počte stretnút' v práci Bytie a čas.

Pred Sartrom priamo a vel'mi dôrazne na túto skutočnost' upozornil E. Husserl v prednáške Fenomenológia a antropológia (1931). Rozhodne odmieta Heideggerove sklony $\mathrm{k}$ antropologizácii, ktoré chápe ako podceňovanie možností filozofie, ktorá dokáže neporovnatel'ne viac, pokial' bude pestovaná ako fenomenológia (Husserl 1999, 975). ${ }^{2}$ Husserlova prednáška sa dodnes cituje ako „Husserlov zákaz antropológie“ (Husserls Anthropologieverbot), ku ktorému sa Heidegger prirodzene pripojil, a to aj

\footnotetext{
${ }^{2}$ Všeobecne povedané, Husserl sa pýta na možnost’ racionálnej metódy, ktorá je potrebná na poznanie faktického sveta vo forme racionálnych, prísnych (exaktných) vied ([...] rationale Methode möglich, um die faktische Welt in Form rationaler Tatsachen-Wissenschaften zu erkennen). Vidí ju vo fenomenológii a tvrdo sa bráni proti vplyvom dobovej antropologizácie a psychologizácie na podobu filozofie. Tí, ktorí stoja na ich strane, teda pre Husserla tiež Heidegger, sú iba „módni filozofi“ (Modephilosophen), o ktorých treba pochybovat', či dokážu poskytnút' filozofii metodické základy prostredníctvom „filozofickej“ antropológie.
} 
preto, aby sa zbavil diskusií o existencializme, ale ešte väčšmi v záujme vnútorného zdôvodnenia Husserlovej ostrej kritiky budovania filozofie z ,hl'adiska l'udského pobytu“ (Husserl 1999, 975).

Či bolo Bytie a čas pre Heideggera osobným úspechom alebo neúspechom, ku ktorému sa podl'a svedectva H.-G. Gadamera prikláňal aj sám Heidegger (Gadamer 2000, 259), a či táto kniha pre dejiny modernej filozofie skutočne znamenala zásadnú zmenu, alebo len vytvorila jej zdanie, je otázka pre d’alšie skúmania historikov filozofie. Pre ciele tejto štúdie je ovel'a zásadnejšie zistit', či a ako Heidegger vymedzil pole svojej konfrontácie s Hegelovým spôsobom chápania otázky bytia. Prvý problém tkvie $\mathrm{v}$ tom, že Heidegger postavil základy fundamentálnej ontológie a neskorý projekt myslenia Bytia na dvoch tézach, ktoré vzbudzujú podozrenie s ohl'adom na svoju kompatibilitu.

Prvá téza vel’mi konkrétne vypovedá o otázke, čo je pre raného Heideggera bytie: „Bytie je vždy bytie nejakého jestvujúcna“ (Heidegger 2008, 25; Heidegger 1977, 12). Druhá téza, ktorá sa stala predmetom Heideggerových filozofických skúmaní v neskorej tvorbe, je formulovaná radikálne opačne: „Odtienit’ bytie od jestvujúceho a explikovat' bytie samo je úlohou ontológie“ (Heidegger 2008, 44; Heidegger1977, 36). Táto druhá pozícia bola pre Heideggera $v$ jeho filozofickom vývoji čoraz dominantnejšia a jej zavŕšenie nájdeme v prednáškach Čas a Bytie (1962) a Koniec filozofie a úloha myslenia (1964). Na javovom nesúlade týchto dvoch pozícií sa ukazuje, že Heidegger sa okrem uvažovaného predmetu skúmania ako bytia jestvujúcna pri hladaní metódy, teda spôsobu ako sa dostat' cez fenomenálnu vrstvu jestvujúceho, dostáva k problematike bytia ako takého. Metodickým konštatovaním, že ontológia nesmie zostat' stát pri jestvujúcom ako existencii, ale je vedená d’alej, k pochopeniu Čistého bytia, a nakoniec k mysleniu Bytia, priviedol Heidegger sám seba na hranicu celoživotného zápasu, ktorý sa stal jeho filozofickým osudom. V tomto kontexte má svoje nezastupitel'né miesto práve jeho konfrontácia s Hegelovou ontologickou koncepciou, voči ktorej sa kriticky vyhraňuje najmä vo svojej neskorej tvorbe.

Heidegger vyjadruje svoje rané ontologické stanovisko v práci Bytie a čas, kde uvádza, že fundamentálna ontológia ako existenciálna analytika pobytu (Heidegger 2008, 29; Heidegger 1977, 18)3 nerieši otázku bytia vôbec, ale len otázku bytia pobytu (Heidegger 2008, 36; Heidegger 1977, 27). Uvedené chápanie fundamentálnej ontológie potvrdzuje aj v roku 1929 v práci Kant a problém metafyziky: „Fundamentálna ontológia sa nazýva oná ontologická analytika konečnej l’udskej bytosti, ktorá má pripravit' základ pre metafyziku, prislúchajúcu prirodzenosti človeka‘. Fundamentálna

\footnotetext{
${ }^{3} \mathrm{~S}$ vedomím diskusií, ktoré prebehli na tému vhodnosti tohto termínu, ponechávam Patočkov preklad nemeckého Dasein ako pobyt.
} 
ontológia je metafyzika pobytu, ktorá je nutná $\mathrm{k}$ tomu, aby bola metafyzika možná“ (Heidegger 2004a, 23; Heidegger 1991, 1).

Podl'a Heideggera sa však koncept metafyziky pobytu samotnou prácou na rekonštrukcii Kantovej nedokončenej filozofie, ktorá sa vyl’akala a vyhla podstatným otázkam, výrazne otriasol. Heidegger si uvedomuje, že ani preňho nebude najlahšie nájst' odpoved' na túto podstatnú otázku, samozrejme, otázku bytia samého. Preto aj celé skúmanie Kantovho chápania metafyziky uzatvára týmto stanoviskom: „Možnože sa fundamentálne ontologicky orientovanou interpretáciou kritiky čistého rozumu problematika založenia metafyziky vyostrila, aj ked' len tak, že ostáva stát pred tým rozhodujúcim“ (Heidegger 2004a, 211; Heidegger 1991, 245). Heideggerovo skúmanie Kantovej Kritiky čistého rozumu je teraz už pochopené ako spochybnenie správnosti cesty, na ktorej hl'adal, preto sa utieka o pomoc k Hegelovi: „Či Kant v druhom vydaní Kritiky čistého rozumu nevrátil vládu intelektu? Nestala sa v jej dôsledku u Hegela metafyzika tak radikálne ako nikdy predtým ,logikou'?" (Heidegger 2004a, 210; Heidegger 1991, 244). To je vel’mi dôležité Heideggerovo vyjadrenie, ktoré je v jeho neskorej tvorbe predmetom mnohých intenzívnych ontologických skúmaní.

\section{Kl'účová otázka metafyziky}

Heidegger sa v roku 1929 vo svojej inauguračnej prednáške Čo je metafyzika? až príliš prekvapujúco otvorene hlási $\mathrm{k}$ Hegelovi: „,Čisté bytie a čisté nič je teda to isté.' Táto Hegelova veta... je plne oprávnená“ (Heidegger 2006b, 71). Plnú oprávnenost' tejto hlavnej vety z Hegelovej práce Logika ako veda (Hegel 1986a, 91) však Heidegger nechápe v Hegelovom duchu, ale len vo svojom vlastnom: „Bytie a Nič patria dohromady, ale nie preto, že - z hl'adiska Hegelovho pojmu myslenia - sú oboje rovnako neurčené a bezprostredné, ale preto, že bytie samo je vo svojom bytovaní konečné a len v transcendencii pobytu, ktorý sa drží vyklonený do Ničoho, sa stáva zrejmým“ (Heidegger 2006b, 70 - 71).

Heidegger sa síce už tu vyjadruje o bytí samom, ale v roku 1929 ho ešte stále zväzuje s konečným bytovaním: oba dôvody, ktoré ho k tomu motivujú, preberá z Hegelovej argumentácie - po prvé, pôvodne Hegelovo odlíšenie čistého bytia a čistého nič mu slúži na vymedzenie kl'účovej otázky metafyziky (ako otázky o bytí samom), a po druhé, zachováva tým ako nedelitel'nú súčast' celku metafyzickej myšlienky aj kategóriu ničoty. Tá je nevyhnutná pre určenie transcendencie pobytu $v$ jeho vyklonení do ničoho a súčasne určuje celkový kontext, $v$ ktorom je problém bytia samého vôbec identifikovatel'ný. Týmto kontextom je celok metafyziky. Heidegger to vysvetl'uje takto: „Ked' je teda otázka bytia ako takého klúčovou otázkou metafyziky, potom sa otázka o Ničom ukazuje ako otázka, ktorá obopína celok metafyziky“ (Heidegger 2006b, $70-71)$. 
Hegel sa pre Heideggera stáva vel'mi svojráznym inšpirátorom prechodu od projektu metafyziky pobytu k novej ontologickej pozícii. Len $\mathrm{v}$ tejto súvislosti potom môže Heidegger tvrdit', že otázka o bytí samom sa stáva „,klúúčvou otázkou metafyziky..." (Heidegger 2008b, 70 - 71). Pre Hegela boli otázky o čistom bytí a čistom nič iba východiskovým bodom jeho ontologického učenia ako najabstraktnejšieho vymedzenia toho, že niečo je. Bytie ako neurčené bezprostredno je bezreflexivne bytie, je iba v sebe samom, je bytím bez kvality. Preto musí prejst' do jestvujúcna. Kým pre Heideggera v roku 1929 znamenajú čisté bytie a čisté nič to najdôležitejšie, čo chce filozoficky skúmat', pre Hegela je zrejmé, že čisté bytie nie je nič iné, iba čistá neurčenost' a prázdnota, nie je $\mathrm{v}$ ňom nič, čo by sa dalo nazerat'. Je teda sui generis prázdnym nazeraním. Hegel vyjadruje svoje ontologické stanovisko v tejto podobe: „Čisté bytie a čisté nič sú teda to isté. Pravdou nie je ani bytie, ani nič, ale to, že bytie - neprechádza -, ale prešlo do ničoho a nič do bytia... Ich pravdou je... tento pohyb [kurz. V. L.], ktorým jedno bezprostredne mizne v druhom: stavanie; pohyb, kde sú obidve rozdielne, ale na základe rozdielu, ktorý sa práve tak bezprostredne stratil“ (Hegel 1986, 91 - 92).

Hegelovo poznanie, že pravdou nie je ani bytie ani nič, ale ich pravdou je pohyb, dianie (das Werden) Heidegger neprijíma. Práve naopak, v d'alších rokoch svojej tvorby sa čoraz viac orientuje na samo bytie bez jestvujúcna, teda bytie bez pohybu. Tým sa postavil do protihegelovskej opozície. Bytie ako neurčené bezprostredno je podla Hegela bez kvality, len jestvujúcno ako „určené bytie... je jestvujúcou určenost'ou, kvalitou. $\mathrm{V}$ dôsledku kvality stojí niečo proti inému, je premenlivé a konečné a naskrze negatívne určené nielen voči inému, ale aj samo v sebe“ (Hegel 1986, 119 - 120). Hegel vo svojom ontologickom uvažovaní vychádza zo základnej axiómy, že otázka bytia je otázkou bytia jestvujúcna. Pre neskorého Heideggera je uvedené východisko neprijatel'né, pretože uzatvára myslenie bytia do klietky tradičnej redukcionistickej metafyziky. Aj preto je Hegel pre Heideggera filozofom, ktorý dejiny tejto metafyziky, v ktorých je filozofia redukovaná na vedu o jestvujúcom, završuje.

\section{Ontologická diferencia}

V súčasných bádatel'ských aktivitách sa čoraz častejšie objavujú stanoviská, podla ktorých je onto-teo-lógia klúčom k mysleniu tzv. neskorého Heideggera (Thomson 2013, 319; de Boer 2000, 116 a n.). Ontologická diferencia (tiež onticko-ontologická diferencia) zaujíma v Heideggerovom učení mimoriadne dôležité miesto. Azda najvýstižnejšie úlohu tohto pojmu opísal H.-G. Gadamer: „Ked’ si spomeniem na prvé Heideggerove prednášky, ktoré som počul v roku 1923 vo Freiburgu a v roku 1924 v Marburgu, vtedy výraz ,ontologická diferencia " pôsobil ako čarovné slovko. Objavoval sa znovu a znovu s oným dôrazom, s ktorým sústredený myslitel' - i bez toho, že by skutočne detailne vyjadril vzt'ahy a význam toho, čo chcel povedat' - dával vediet', že sa tu usiluje o čosi 
absolútne rozhodujúce. Taký už bol spôsob reči mladého Heideggera. Tento výraz fungoval takmer ako iné bežné príslovie, ktorým sme boli vel'mi často odbití, ked' sme sa na seminári pokúšali predniest' svoje vlastné myšlienkové pokusy a drobné príspevky. Heidegger potom povedal: ,Áno, áno - ale to je ontické, nie ontologické ““ (Gadamer 1999, 138). Výraz ontologická diferencia ostal teda v pozícii čarovného slovka bez toho, aby detailne vyjadril vzt'ahy a význam toho, čo chcel povedat'.

V Heideggerovom filozofickom vývoji je fascinujúco zakódované jeho váhanie, doslova zápasenie s otázkou bytia a jestvujúcna a ich vzájomného vzt’ahu, teda ontologickou diferenciou. ${ }^{4}$ Najpresvedčivejšie to máme vyjadrené v jeho Doslove $k$ prednáške Čo je metafyzika? zo štvrtého vydania z roku 1943. Kým v ostatných vydaniach Heidegger piše, že „k pravde bytia patrí, že bytie nikdy nebytuje bez jestvujúcna, a že jestvujúcno nie je nikdy bez bytia“, s čím možno súhlasit', vo štvrtom vydaní uvádza, že „bytie síce bytuje bez jestvujúcna, ale že jestvujúcno nie je nikdy bez bytia“ (Heidegger 2006b, 82 - 83). Tu sme v jadre nášho skúmaného problému, ktorý možno vyjadrit' takto: môže bytie bytovat' bez jestvujúcna? Domysliet' ontologickú diferenciu dokonca potom znamená prijat' takýto záver. A Heidegger to vo svojom neskorom období aj naozaj urobí!

Lenže kým sa to stane, treba objektívne konštatovat', že Heidegger sa v tridsiatych a štyridsiatych rokoch dvadsiateho storočia postupne zaoberá skúmaním nemeckého

\footnotetext{
${ }^{4} \mathrm{~V}$ stati nie je ciel'om podrobit' skúmaniu problém ontologickej diferencie v celej jeho šírke, zložitosti a protirečivosti. Sú bádatelia, ktorí sú presvedčení, že Heidegger svoje stanovisko k ontologickej diferencii vo svojej neskorej tvorbe opúšt’a a tento svoj obrat aj zdôvodňuje. Vychádzajú pritom z Heideggerových textov z konca šest'desiatych a začiatku sedemdesiatych rokov minulého storočia, ktoré boli publikované len prednedávnom (Heidegger 2013a, 1326 a n.) a spájajú Heideggerovu kritiku metafyziky s príklonom k chápaniu „veci myslenia“, ktorý nevedie k rezignácii filozofie, ale k jej uchopeniu zo stanoviska „druhého počiatku“. Každý bádatel' má právo na svoj názor v predmetnom probléme, ale vel'mi presne to formuluje zostavovatel' citovaného zväzku 73/2 Peter Trawny, ktorý $\mathrm{v}$ doslove napísal, že pochopit' práve tieto Heideggerove fragmentárne texty je už len na čitatel'ovi samom a jeho „vlastných pokusoch o interpretáciu“ (Heidegger 2013a, 1491). Heidegger nám v celej svojej tvorbe ponúka príležitost' hl’adat' našu vlastnú „cestu“ pochopenia problémov, o ktoré mu ide. A to najmä v probléme ontologickej diferencie, teda či „bytie bytuje bez jestvujúcna, alebo nie“. Ostáva potom len na čitatel'ovi, aby si to sám rozhodol, ku ktorému riešeniu sa chce pridat'. A pokial' ide o problém „druhého počiatku“, ktorý nemá viest' k rezignácii filozofie, musím konštatovat', že vlastné Heideggerove slová pri príležitosti jeho osemdesiatych narodenín sú nespochybnitel'ným dôkazom presného opaku: „Jednu svoju prednášku, ktorá sa konala v Paríżi roku 1964... som nazval Koniec filozofie a úloha myslenia. Robím teda rozdiel medzi filozofiou, tzn. metafyzikou, a myslením, ako ho ja chápem. Myslenie, ktoré v tejto prednáške od filozofie odlišujem - predovšetkým tým, že sa tu pokúšam o vyjasnenie bytnosti gréckej alétheia -, toto myslenie je z podstaty veci v porovnaní s metafyzickým omnoho jednoduchšie než filozofia, ale vo svojej realizácii práve pre svoju jednoduchost' d'aleko obt’ažnejšie“ (Heidegger 2013b, 49). Odmietnutím filozofie ako metafyziky sa Heidegger definitívne zbavil aj problému ontologickej diferencie. Avšak v mysliacom rozhovore s Hegelom, ktorý je predmetom tejto štúdie, ontologická diferencia má svoju nezastupitel'nú úlohu. Preto jej venujem takú vel'kú pozornost'.
} 
idealizmu, najmä Hegela. Začiatok tohto úsilia predstavuje prednáškový kurz Nemecký idealizmus (Fichte, Hegel, Schelling), ktorý chápe ako Historickú správu o nemeckom idealizme (Heidegger 1997, 1; podrobnejšie pozri Leško 2017a, 255 - 273). Po ňom nasleduje prednáškový kurz Hegelova Fenomenológia ducha (Heidegger 1997), ale najmä traktát o negativite z rokov 1938 - 1939 (Heidegger 1993; podrobnejšie pozri Leško $217 \mathrm{c}, 657$ - 677). Pre všetky Heideggerove ontologické aktivity riešené vo vyššie uvedených prednáškových kurzoch platí, že je navyše výrazným obhajcom metafyziky ako učenia o bytí. Ked' sa pokúša o fundovanú odpoved' na túto otázku v polovici pät'desiatych rokov minulého storočia, ocitá sa už náhle medzi kritikmi metafyziky. Najvýraznejšie sa to prejavilo v novom chápaní metafyziky ako onto-teo-lógie. Dokladajú to najmä jeho dve prednášky z pät'desiatych rokov minulého storočia. Prvá bola prednesená v roku 1957 a má názov Onto-teo-logická konštitúcia metafyziky (Heidegger 1998, 51 - 79; podrobnejšie pozri Leško 2017d, 761 - 778). Druhá s názvom Hegel a Gréci odznela v roku 1958 (Heidegger 1976, 427 - 444; podrobnejšie pozri Leško 217d, 799 - 820). Pre obe prednášky je určujúce, že sú koncipované ako Heideggerov mysliaci rozhovor s Hegelom.

\section{Metafyzika ako onto-teo-lógia}

Pojem onto-teo-lógie sa objavuje prvýkrát v dejinách filozofie v Kantovej Kritike čistého rozuти a vyjadruje kritiku každej teológie budujúcej na špekulatívnych princípoch rozumu. Kantovi ide o dešifrovanie problému existencie prabytosti (teda boha) na pôde transcendentálnej teológie (Kant 1979, 391). Heidegger problém onto-teo-lógie posunie z transcendentálnej teológie na metafyzicko-ontologické myslenie, a tým celý problém dostane úplne nový rozmer. Ide totiž o to, že pokial' budeme chápat' západnú metafyziku ako onto-teo-lógiu a zároveň k tomu budeme pridávat', že Hegel je zavíšitel'om tohto dejinného typu metafyziky, potom budeme musiet' súhlasit's tým, že aj Hegelova metafyzika je onto-teo-lógiou. Je to však správne hodnotenie? Prvý Heideggerov pokus uchopit' problém zaviršenia Hegelovej metafyziky ako zavíšenia západnej metafyziky vôbec sa uskutočnil v letnom semestri roku 1933 v prednáškovom cykle Základná otázka filozofie. Ide mu v ňom o predstavenie základného charakteru Hegelovej metafyziky s dôrazom na jej určenie ako teo-logiky, teda ako logiky systému $a b$ solútneho sebauvedomenia boha (Heidegger 2001, 70).

Nový Heideggerov pokus charakterizovat' Hegelovu metafyziku je pokusom hl'adat' to, čo má jeho filozofovanie spoločné s Hegelovou ontológiou a kde sa podstatne rozchádzajú (Heidegger 2006c, 52 - 53). Spoločné nachádza v tom, že im ide o pochopenie a skúmanie veci myslenia. Pre Hegela je vecou myslenia myslenie ako také, teda pojmové myslenie vo svojej rozvíjajúcej sa jednote. Hegel sa nepochybne zameral na skúmanie vývoja myslenia, ktoré sa rozvinie do najvy̌̌šej podoby v absolútnej idey. 
V diele Logika ako veda sa píše: ,... len absolútna idea je sama bytím, nepominutel’ným životom, o sebe vediacou pravdou, a to všetkou pravdou“ (Hegel 1986b, 478). Preto Heidegger konštatuje, že „Hegel dáva dôrazne svojmu predmetu myslenia jediné meno, ktoré stojí nad samou vecou celého myslenia, a týmto menom je: bytie“ (Heidegger 2006c, 52-53).

Heidegger chce v mysliacom rozhovore s Hegelom uvažovat' o viacvýznamovom, ale aj o jednoznačnom použití pojmu bytie, ale to hlavné si všíma vel'mi špecificky. Hegel vymedzuje bytie ako neurčenú bezprostrednost', teda ako to, o čom môžeme zmysluplne vypovedat' len to, že je. Bytie, čisté bytie, je podl’a Hegela „rovné iba sebe samému... Bytie je čistá neurčenost' a prázdnota... Bytie, neurčené bezprostredno, je fakticky ničím, a nie je ani viac, ani menej než nič““ (Hegel 1986a, 90 - 91).

Hegel preto mohol na tomto základe l'ahko zdôvodnit' logiku ako metafyziku, teda ako učenie o bytí. Heidegger prijíma toto určenie a pokladá ho za nespochybnitel'nú filozofickú pozíciu takmer v celej svojej tvorbe. Avšak spôsob Heideggerovho vel'mi výberového čítania diel svojich predchodcov je aj v prípade Hegela vel'mi zaujímavý. Heidegger si totiž vôbec nevšíma vel'mi dôležitý Hegelov argument: „Pravdou nie je ani bytie, ani nič, ale to, že bytie neprechádza, ale prešlo do ničoho a nič do bytia. Práve tak pravdou nie je ich nerozdielnost', ale to, že nie sú to isté, že sú absolútne rozdielne, lenže takisto aj neoddelené a neoddelitel’né, a že každé bezprostredne mizne vo svojom opaku. Ich pravdou je teda tento pohyb, ktorým jedno bezprostredne mizne $\mathrm{v}$ druhom: stávanie - pohyb, kde sú obidve rozdielne, ale na základe rozdielu, ktorý sa práve tak bezprostredne stratil“" (Hegel 1986a, 91 - 92).

Z uvedeného je zrejmé, že Hegelovi nejde o nijaké statické chápanie jestvujúceho, ale o dynamické pochopenie skutočnosti, o pochopenie jestvujúceho v pohybe. No Heideggera práve táto skutočnost' vôbec nezaujíma. Preňho ostáva rozhodujúce vyjadrenie v tejto podobe: Bytie je pravdou a len Ono je Pravdou. Do akej miery nám to môže právom pripomínat' teologický variant Pravdy: Boh je Pravda a len On je Pravda, to si už musí zodpovedat' každý čitatel' sám.

U Hegela je nespochybnitel'né, že bytie ako také je pevne zviazané s myslitel'nostou jestvujúceho $\mathrm{v}$ absolútnom myslení. Inak vyjadrené, bytie je vždy len bytím jestvujúcna. To však nie je Heideggerov prípad v neskorej fáze jeho myšlienkového vývoja. Diferencia bytia a jestvujúcna je to, čo vedie Heideggerovo filozofické úsilie priamo a neodvolatel'ne k svojmu zavíšeniu, ktoré sa v plnej sile prejaví v chápaní bytia bez jestvujúcna. Najparadoxnejšie vyjadrenie uvedeného chápania nachádzame $\mathrm{v}$ jeho prednáške Kantova téza o bytí (1961): „Bytie nemôže byt. Keby bolo, nebolo by už bytím, ale bolo by jestvujúcnom [kurz. V. L]“ (Heidegger 1976, 479).

Hlavný Heideggerov argument pre zdôvodnenie onto-teo-logickej štruktúry metafyziky je vyjadrený v tejto podobe: „Onto-teo-logická konštitúcia metafyziky 
pochádza z vlády diferencie, bytia ako základu (Grund)..." (Heidegger 2006c, 76). Pochopitel'ne, tento argument predpokladá najprv uverit' a potom už len prijat' vládu diferencie. Ked' sa to nestane, aj celkový výsledok bude vyzerat' úplne inak. Podla Heideggera boh prichádza do filozofie ako prejav bytnosti diferencie bytia a jestvujúcna. Ontologická diferencia v Heideggerovom chápaní je v uvedenej prednáške prejavom silného modelu diferencie, lebo nie je možné žiadne iné dôležitejšie určenie, o ktoré mu v prípade bytia ide. To však nie je pravdou. Môže existovat' aj slabý model diferencie, ktorý je postavený na rozlíšení bytia a jestvujúcna, a zároveň je toto rozlíšenie skúmané na nespochybnitel’nom chápaní bytia jestvujúcna, a nie na hladaní možnosti identifikovat' samo bytie bez jestvujúcna.

Slabý model diferencie je realizovaný v Hegelovej Logike. V tejto súvislosti je vel'mi zaujímavá skutočnost', že túto podobu diferencie si Heidegger uvedomuje až pridobre. Svedčia o tom najmä jeho hodnotenia Hegelovho chápania bytia i jeho logiky: „Hegel myslí bytie v jeho najprázdnejšej prázdnote, takže vo všeobecnosti. Myslí zároveň bytie $v$ jeho nekonečnej bezchybnej plnosti súčasne a nepomenúva špekulatívnu filozofiu, teda skutočnú filozofiu onto-teológiou, ale vedou logiky. S týmto pomenovaním prináša Hegel pre objasnenie niečo rozhodujúce. Mohlo by sa vol'né pomenovanie metafyziky ako logiky prostredníctvom odkazu vysvetlit' tak, že to môže byt' predsa pre Hegela vec myslenia - myšlienka, slovo ako jednotné tantum. Myšlienka, myslenie je zrejmé a podl'a starého použitia je tiež témou logiky. Ale taktiež je presne dané, že Hegel bol verný tradícii a dejinám veci myslenia $\mathrm{v}$ bytnosti ako takej a v celistvosti, $\mathrm{v}$ ktorej sa deje pohyb bytia od jeho prázdnoty k rozvíjajúcej sa plnosti“ (Heidegger 2006c, 57).

Hegel vo svojej Logike ako vede, v jej východiskovej náuke, náuke o bytí, vel'mi jasne uvádza, že ,to, čo o bytí vypovedajú alebo z neho obsahujú bohatšie formy predstavovania absolútna alebo boha, je na začiatku iba prázdne slovo a iba bytie; toto jednoduché, ktoré nemá d’alší význam, toto prázdne je teda naskrze začiatkom filozofie“ (Hegel 1986a, 87). To, čo chce Hegel skúmat' vo svojej logike, nie je Bytie samo a jeho Pravda, ako je to v Heideggerovom prípade, ale chce sa sústredit' na jestvujúcno ako určené bytie (Hegel 1986a, 119). V tejto filozofickej pozícii je azda najreprezentatívnejšie vyjadrená sila slabého modelu, na rozdiel od Heideggerovho silného modelu ontologickej diferencie.

V Hegelovom chápaní metafyziky zásadne absentuje chápanie jestvujúceho v jednote s najvyšším jestvujúcnom - bohom. Pritom je zaujímavé, že Heidegger vel’mi správne uvádza príklad, ktorý použil Hegel v Malej logike (§ 13) (Hegel 1961a, 18; Hegel 1992, 53) a ktorý nám až neuveritel’ne jednoducho vyjadrí doteraz tak komplikovane vysvetl'ované problémy. Niekto si chce na trhu kúpit' ovocie. Žiada si ovocie. Predavač mu ponúka jablká, hrušky, broskyne, čerešne, hrozno... Ale kupujúci stále ponuku odmieta. Za každú cenu si chce kúpit' iba ovocie. To však nie je možné. Dôvod 
je viac ako pochopitel'ný. Zakaždým je ponúkaný len konkrétny druh ovocia, preto sa ovocie ako také nedá kúpit'. Aj bytie jestvuje vždy a stále len v takej podobe ako bytie konkrétneho jestvujúcna. Lenže to Heidegger odmieta a chce ustavične hl'adat' d’alej Bytie bez vzt’ahu k jestvujúcnu, lebo myslenie Bytia nemá podl'a neho hladat' oporu v jestvujúcne. Ked' sa to deje, tak podl'a neho už vždy ide len o jestvujúcno, a nie o Bytie samo.

\section{Hegel, Gréci a vec myslenia}

Excelentný Heideggerov filozofický pokus viest' mysliaci rozhovor s Hegelom v otázke veci myslenia a z nej vyplývajúceho myslenia Bytia predstavuje jeho prednáška Hegel a Gréci (1958). Prednáška je charakteristická svojou špecifickou metódou, za pomoci ktorej Heidegger vysvetl'uje Hegelovo chápanie gréckej filozofie v kontexte Hegelovho systému ako takého. Ide teda o aplikáciu historickej metódy na súčasný problém filozofie. Heideggerovi ide o prienik do vecí myslenia a skúma, ako tento problém rieši Hegel a v jeho interpretácii aj starí grécki filozofi. Obchádzka cez Hegela až ku Grékom je vel'ká a právom vzbudzuje otázku, či je vôbec pre nahliadnutie problému veci myslenia potrebná. Heideggerova odpoved' je však jednoznačná. Potrebuje práve túto cestu, ktorá svojou podstatou nie je obchádzkou, ale sprostredkovaním duchovného dedičstva, ktoré prestáva byt' čŕrou minulost'ou a vynára sa pred nami ako plne súčasná vec myslenia (podrobnejšie pozri Leško 2013, 194 -204).

Heidegger vel'mi správne hodnotí Hegelov filozofický spôsob chápania gréckej filozofie a preukazuje mu až prekvapujúco vysoké uznanie :,,.. Hegel prvýkrát myslí grécku filozofiu ako celok a tento celok filozoficky“" (Heidegger 1976, 428; pozri tiež Leško 2010, 110 - 119). Ba čo viac, Heidegger je presvedčený, že Hegel nevysvetl'uje dejiny filozofie, on o nich filozoficky premýšla. Heidegger správne hodnotí, že žiadny filozof pred Hegelom nespoznal, že filozofovanie samo sa ,pohybuje vo svojich dejinách a že tento pohyb je filozofiou samou“ (Heidegger 1976, 429). Tým Hegel prvýkrát v dejinách filozofie otvoril možnost' pre vznik filozofie dejín filozofie. Vo filozofii dejín filozofie ide teda o vec myslenia. Je to možné aj preto, ako to zdôvodňuje Heidegger, že dejiny filozofie sa stali pre Hegela jednotným a nevyhnutným procesom pohybu ducha k sebe samému. Potial' je to všetko v poriadku.

Problém sa však začína pri chápaní a vysvetlení gréckej filozofie, ako to uskutoční Heidegger, ked’že celá jeho prednáška sa takmer výlučne sústred’uje len na skúmanie štyroch základných určujúcich slov gréckej filozofie (Jedno - Parmenides, Logos - Herakleitos, Idea - Platón, Skutočnost' - Aristoteles). Tieto grécke slová podl'a Heideggera vyjadrujú jej nespochybnitel'nú bytnost' $\mathrm{v}$ súvislosti s hlavným pojmom filozofie vôbec, teda s pojmom bytie. Tu si musíme uvedomit' skutočný filozofický rozdiel medzi Hegelovou a Heideggerovou recepciou gréckej filozofie. Hegelovi ide naj- 
mä o pochopenie gréckej filozofie ako celku, kým Heideggerovi ide o pochopenie štyroch základných pojmov a ich správne vysvetlenie, teda o preukázanie toho, čo chce sám dosiahnut' pri riešení otázky bytia (podrobnejšie pozri Leško 2017e, 807).

Pre Hegela a Heideggera je v ich chápaní gréckej filozofie spoločné najmä to, že sa v jej rozhodujúcom poznaní odvolávajú na Parmenida a Herakleita. Hegel to urobil vo svojich Prednáškach o dejinách filozofie takto: „Parmenidom sa začala skutočná filozofia...“" a zároveň dodáva, že „... len bytie je pravdivé“ (Hegel 1961b, 227). Heidegger zasa tvrdí, že Herakleitos a Parmenides ešte neboli filozofmi, pretože „,boli väčšími myslitel'mi““ (Heidegger 2006, 1216 - 127; pozri tiež Leško 2013, 194 - 204). Slovom väčš Heidegger nerozumie vyjadrenie teoretického výkonu, ale poukázanie na inú dimenziu myslenia. Táto dimenzia jednoducho znamená orientovat' sa na skúmanie bytia, a nie na skúmanie jestvujúcna. Pregnantne to vyjadril v Liste o humanizme: ,,Bytie je'; lebo obvykle sa ono ,je' hovorí o niečom takom, čo je. Niečo také nazývame jestvujúcno. Bytie však práve ,nie je‘ , jestvujúcno ‘... Ved’ už na počiatku myslenia Pramenides hovorí: ..., Ved' bytie je‘. V tomto slove sa skrýva počiatočné tajomstvo všetkého myslenia. Hádam môže byt' ono, je' primerane vyslovené len bytím, takže všetko jestvujúcno vlastne ,nie je““ (Heidegger 1976, 334 - 335; Heidegger 2000, 25 - 26).

Vyššie uvedené hodnotenia Parmenidovho učenia môžeme prekvapujúco chápat' aj ako takmer úplnú zhodu medzi Hegelom a Heideggerom. Obidvaja totiž tvrdia, že Parmenides vypovedá o bytí. V čom je teda problém? A problém je naozaj vel'mi vel'ký. Hegel pod Parmenidovým chápaním bytia rozumie bytie jestvujúcna, kým Heidegger v ňom vidí bytie bez jestvujúcna. Heidegger je už od roku 1923 presvedčený, že Parmenidovo učenie o bytí je rozhodujúcim krokom, „ktorý určil zmysel a osud západnej ontológie a logiky“ (Heidegger 2008b, 33). To je však vo vel'kom protiklade $\mathrm{k}$ tomu, čo si myslí Hegel o Parmenidovi. Učenie tohto predsokratovského filozofa o tom, že jestvujúce je a nejestvujúce nie je, chápe ako nejasný a neurčitý počiatok, ktorý „nemožno d’alej vysvetlit, čo je v ňom skryté...“ (Hegel 1961b, 227). A v tom môžem s Hegelom aj dnes súhlasit'. Heidegger sa pustil presne opačnou cestou a chce nejasný a neurčitý počiatok urobit' jasným. Ukáže sa, že snaha prisúdit' Parmenidovi učenie o Bytí samom nebola jeho najšt'astnejším riešením.

Hegel sa z dvojice najvýznamnejších predsokratovských filozofov jednoznačne priklonil na stranu Herakleita: „Niet jedinej Herakleitovej vety, ktorú by som nebol pojal do svojej Logiky“ (Hegel 1961, 245). Hegelovo učenie o bytí sa právom hlási k Herakleitovi pre to najdôležitejšie, čo chce sám vyjadrit’ v učení o bytí: „Bolo hlbokým poznaním, ked'sa nahliadlo, že bytie a nebytie sú abstrakcie bez pravdivosti, že až dianie je prvou pravdou [kurz. V. L.]“" (Hegel 1961b, 249). K tomu vari netreba d'alej nič dodávat'. 


\section{Koniec metafyziky a vec myslenia}

Heidegger sa v roku 1964 vo svojej neskorej tvorbe, v prednáške Koniec filozofie a úloha myslenia, pokúša vytýčit' nové možnosti úlohy myslenia. Chce odhalit', ako d’aleko kritická otázka, čo je vec myslenia, nutne a stále patrí k mysleniu (Heidegger 2006a, 6 - 7 a n.). Formulácia tejto otázky má za úlohu d’alej precizovat' jeho starý problém otázku bytia. Rozhodujúca zmena nastupuje v tom, že Heidegger chce teraz už otvorene podrobit’ priamo formulovanej imanentnej kritike položenie otázky z Bytia a času. To je novum $\mathrm{v}$ jeho tvorbe, ktoré si musíme nielen všimnút', ale sa ho aj stále držat', ak máme správne identifikovat' jeho neskorú myslitel'skú pozíciu. Výsledok tejto imanentnej kritiky je priam šokujúco zaujímavý.

Heidegger začína svoju prednášku vel’mi razantne. Bez akýchkol'vek rozpakov ide k jadru veci: „Filozofia je metafyzika. Metafyzika myslí jestvujúcno v celku - svet, človeka, boha - čo sa týka bytia, čo sa týka spolunáležitosti jestvujúcna v byti“ (Heidegger 2006a, 6 - 7). S Heideggerom možno súhlasit' bez výhrad iba v tom, že pôvodne zamýšl’aná metafyzika chcela skúmat' jestvujúcno ako jestvujúcno spôsobom zdôvodnuujúceho, zakladajúceho predstavovania. Bytie jestvujúcna, tvrdí Heidegger, sa od za-

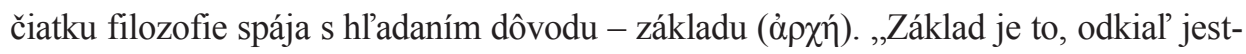
vujúcno ako také vo svojom vznikaní, zanikaní a trvaní... je, čím je a ako je. Bytie ako základ privádza každé jestvujúcno a umožňuje mu jeho chvílu prítomnit'. Základ sa ukazuje ako prítomnenie. Jeho prítomnost' tkvie v tom, že to, čo je vždy tým-ktorým spôsobom prítomné, vyvoláva do prítomnenia“ (Heidegger 2006a, 8 - 9; pozri tiež Leško 2017f, 821 - 842).

Heidegger túto podobu metafyzického myslenia jednoznačne odmieta, preto ju spája s koncom filozofie. Len v tejto väzbe je koniec filozofie pochopitel'ný a možno ho vlastne zároveň určit’ ako doviršenie metafyziky. Heidegger teraz už dôvodí: „V celých dejinách filozofie zostáva v obmenených podobách smerodajné Platónovo myslenie. Metafyzika je platonizmus“ (Heidegger 2006a, 8 - 9). Metafyzika vznikla, rozvíjala sa a stále môže preživat' len ako platonizmus. Keby to tak nebolo, tak nejde o metafyziku $\mathrm{v}$ tradičnom, klasickom zmysle slova. Heidegger zároveň upozorňuje, že by sme nemali zabúdat', že v období gréckej filozofie sa objavil zároveň jeden z rozhodujúcich rysov filozofie - vytvorenie vied v rámci obzoru, ktorý filozofia otvorila.

Vytvorením vied sa podla Heideggera dali do pohybu aj procesy ich odklonu od filozofie a sústavné hl’adanie i napíñanie ich teoretickej samostatnosti. Práve najmä tento vývin Heidegger identifikuje ako dovíšenie filozofie. Súhlasit’ možno s tým, že z filozofie v jej počiatkoch v Grécku sa naozaj postupne vydel'ujú jednotlivé vedy. Či to však znamená dovŕšenie fillozofie, o tom treba pochybovat'. Ale najmä o tom, čo je heideggerovsky svojrázne vyjadrené v tejto podobe: „Koniec filozofie sa ukazuje ako triumf riaditel'ného ustanovovania vedecko-technického sveta a tomuto svetu primera- 
ného spoločenského usporiadania. Koniec filozofie znamená: počiatok svetovej civilizácie založenej v západoeurópskom myslení“ (Heidegger 2006a, 12 - 13). Samozrejme, že s Heideggerovou tvorbou filozofia nezanikla. Zanikla iba jedna podoba ontologického uvažovania vo filozofii dvadsiateho storočia. Heidegger na sklonku svojho života už len rezignovane konštatuje, že filozofia ešte nedorástla na vec myslenia (Heidegger 2012, 49). V tomto kontexte Heidegger podmieňuje úlohu myslenia spätným pohl'adom do celku dejín filozofie. Lenže pokial' niečo v Heideggerovej tvorbe v porovnaní s Hegelom naozaj chýba, tak je to najmä úsilie o reflektovanie celku dejín filozofie. Rovnako otázne je však aj to, do akej miery Heideggerove filozofické iniciatívy reflektujú dejinnost' filozofie, ked’že skutočnou - a stále jedinou - otázkou filozofie je len jedna a stále tá istá otázka - otázka bytia. Redukcia filozofie na riešenie práve tejto jednej jedinej otázky je pre ňu absolútne sebazničujúca. O tom vôbec nemožno pochybovat'.

Heidegger sa v prednáške Koniec filozofie a úloha myslenia rigorózne vyslovuje za jasnú deliacu čiaru medzi vecou filozofie a vecou myslenia. „Vecou filozofie ako metafyziky je bytie jestvujúcna, jeho prítomnenie v podobe substanciality a subjektivity“ (2006a, 16 - 17). Vecou myslenia je však reflektovat' vec samu, čo znamená mysliet' tak, že to ,už nemôže byt' vecou filozofie“ (Heidegger 2006a, 18 - 19), teda nepýtat’ sa na bytie jestvujúcna, ale na Bytie samo (pozri tiež Leško 2015, 429-439). Heidegger neskrýva, že podstata toho, o čom všetkom uvažuje, je zahalená do zjavného rúcha temnoty a neistoty. A v tom s ním môžem plne súhlasit'.

Hoci Heidegger vo svojej tvorbe na chvíl'u ešte vykreše st’aby novú iskierku nádeje učením o alétheii a svetline, bude to však skutočne trvat' iba chvíl'ku. Záverečná etapa jeho tvorby je už viac-menej jednoznačne rezignujúco-pesimisticko-teologizujúca: „Vidím jedinú možnost’ záchrany, totiž v myslení a básnení sa pripravovat' na to, že sa objaví boh, alebo na to, že boh nebude nášmu zániku prítomný, aby sme totiž, hrubo povedané ,nepošli‘, ale ked' už zanikneme, aby sme zanikli pred tvárou boha neprítomného (Heidegger 2012, 33). Je to šokujúce vyjadrenie, ked’ si uvedomíme, že Heidegger kritizuje tradičnú metafyziku vrátane Hegelovej, ako jej zaviršenie, ako onto-teo-lógiu. Pritom sám sa v záverečnej fáze svojho myslenia odvoláva na Boha tak, ako by to Hegel nikdy neurobil. Dôvod tejto skutočnosti je u Hegela viac ako pochopitel'ný. Nikdy totiž vo svojej metafyzike nechápal boha ako bohočloveka, ale len ako neosobného boha v spinozovskom duchu, teda ako substanciu.

Neskorý Heidegger identifikuje najväčšiu nespokojnost' s neprítomnost'ou žiadneho myslitel'a, ktorý by bol dost' vel'ký na to, aby sa zaoberal otázkou Bytia samého (Heidegger 2012, 49). Uvedené Heideggerovo sebakritické vyjadrenie len potvrdzuje pravdivost' toho, že úsilie zdôvodnit' myslenie Bytia, ktoré nehl'adá oporu v jestvujúcne, sa nedá zodpovedne naplnit'. Možno aj preto až teraz, v skúmanej prednáške konečne 
prizná to, že ani Parmenides výslovne neuvažoval o Bytí samom, ale len a len o bytí jestvujúcna (Heidegger 2006a, 28 - 29).

\section{Záver}

Heidegger pred seba vo svojej tvorbe postavil neriešitel'ný problém. Filozofický osud si určil sám už v roku 1931, ked' vyriekol slová o tom, že sa chce postavit' na hranicu pochopitel'ného (Heidegger 2001b, 27). A on sa tam skutočne aj postavil, ba v mnohom a často ju aj prekračoval. Riziko tohto krajného ontologického úsilia si však nevyhnutne vyžiadalo svoju vel'kú daň - defetistickú rezignáciu. V žiadnom prípade to však neznamená, že jeho filozofický výkon bol zbytočný. Tak v dejinách vedy, ako aj v dejinách filozofie platí, že k jej výsledkom patria nielen úspechy, ale aj omyly. Heideggerove myslitel'ské cesty len potvrdzujú, že filozofia ako metafyzika je schopná vyslovit' sa k otázke bytia jestvujúcna, nie však k otázke Bytia samého. Túto otázku Heidegger vysunul mimo filozofie ako metafyziky, ale nebol schopný ju naplnit' tak, ako si sám pôvodne myslel. Redukcia filozofie na metafyziku bola $\mathrm{v}$ jeho prípade pre filozofiu sebadeštruktívna. Najlepšie to sám vyjadruje formuláciou, že nasledovat' Heideggera nemá žiadny zmysel. Bud' budeme viest' jeho problematiku iným smerom, alebo jej budeme oponovat' (Heidegger 2013b, 25). Heideggerov mysliaci rozhovor s Hegelom pokladám za to najcennejšie, čo nám odkázal tento nemecký myslitel’ dvadsiateho storočia, v ktorom sa Hegel môže právom chápat' ako kritik Heideggera. V mnohom potom zápas nemeckých gigantov myslenia dostáva svoj neopakovatel’ný súčasný rozmer.

\section{Literatúra}

BOER de, K. (2000): Thinking in the Light of Time. Albany: State University of New York Press.

CAPOBIANCO, R. (2010): Enganging Heidegger. Toronto - Buffalo - London: Inuversitz if Toronto Press.

GADAMER, H.-G. (1989): Hermeneutik und ontologische Differenz. GWX, Tübingen, J. C. B. Mohr/ Paul Siebeck.

GADAMER, H.-G. (1999): Člověk a řeč. Prel. J. Sokol, J. Čapek. Praha: Oikoymenh.

GADAMER, H.-G. (2000): Filosofie mezi vědou a přirozeným světem. In: Fenomén jako filosofický problém. Chvatík, I. - Kouba, P. (eds.). Praha: Oikoymenh.

GADAMER, H.-G. (2008): Heideggeriov „, theologický spis “ z mládí. In: Heidegger, M. (2008b).

HEGEL, G. W. F. (1961a): Logika. Prel. T. Münz. Bratislava: Vydavatel'stvo SAV.

HEGEL, G. W. F. (1961b): Dějiny filosofie. Prel. J. Cibulka, M. Sobotka. Praha: Nakladatelství ČSAV.

HEGEL, G. W. F. (1986a): Logika ako veda I. Prel. T. Münz. Bratislava: Nakladatel'stvo Pravda. HEGEL, G. W. F. (1986b): Logika ako veda II. Prel. T. Münz. Bratislava: Nakladatel'stvo Pravda. HEGEL, G. W. F. (1992): Malá logika. Prel. J. Loužil. Praha: Svoboda.

HEIDEGGER, M. (1976a): Hegel und Griechen. In: Heidegger, M.: Wegmarken. GA. Bd. 9. Frankfurt am Main: Vittorio Klostermann. 
HEIDEGGER, M. (1976b): Kants These über das Sein. In: Heidegger, M.: Wegmarken. GA. Bd. 9. Frankfurt am Main: Vittorio Klostermann.

HEIDEGGER, M. (1976c): Brief über des Humanismus. In: Heidegger, M.: Wegmarken. GA. Bd. 9. Frankfurt am Main: Vittorio Klostermann.

HEIDEGGER, M. (1991): Kant und das Problem der Metaphysik. GA. Bd. 3. Frankfurt am Main: Vittorio Klostermann.

HEIDEGGER, M. (1993): Hegel. GA. Bd. 68. Frankfurt am Main: Vittorio Klostermann.

HEIDEGGER, M. (2000): O humanismu. Prel. P. Kurka. Rychnov nad Kněžnou: Ježek.

HEIDEGGER, M. (2001a): Grundfrage der Philosophie. In: Heidegger, M.: Sein und Wahrheit. GA. Bd. 36/37. Frankfurt am Main: Vittorio Klostermann.

HEIDEGGER, M. (2004a): Kant a problém metafyziky. Prel. J. Pechar et al. Praha: Filosofia $\varphi \imath \lambda 0 \sigma 0 \varphi 1 \alpha$

HEIDEGGER, M.(2006a): Konec filosofie a úkol myšlení. Prel. I. Chvatík. Praha: Oikoymenh.

HEIDEGGER, M. (2006b): Co je metafyzika? Prel. I. Chvatík. Praha: Oikoymenh.

HEIDEGGER, M. (2006c): Básnicky bydli člověk. Prel. I. Chvatík. Praha: Oikoymenh.

HEIDEGGER, M.(2006d): Die onto-theo-logische Verfassung der Metaphysik. In: Heidegger, M. Identität und Differenz. GA. Bd. 11. Frankfurt am Main: Vittorio Klostermann.

HEIDEGGER, M. (2007): Zur Sache des Denkens. GA. Bd. 14. Frankfurt am Main: Vittorio Klostermann.

HEIDEGGER, M. (2008a): Bytí a čas. Prel. I. Chvatík, P. Kouba, M. Petř́íck jr., J. Němec. Praha: Oikoymenh.

HEIDEGGER, M. (2008b): Rozvrh fenomenologické interpretace Aristotela. Prel. I. Chvatík. Praha: Oikoymenh.

HEIDEGGER, M. (2012): , Už jenom nějakýbi̊h nás může zachránit“. Prel. I. Chvatík. Praha: Oikoymenh.

HEIDEGGER, M. (2013a): Zum Ereignis - Denken. GA. Bd. 73.2. Frankfurt am Main: Vittorio Klostermann.

HEIDEGGER, M. (2013b): Rozhovory k osemdesátým narozeninám. Prel. I. Chvatík. Praha: Oikoymenh.

HUSSERL, E. (1999): Fenomenologie a antropologie. In: Filosofický časopis, 47 (6), 975 - 988.

KANT, I. (1979): Kritika čistého rozumu. Prel. T. Münz. Bratislava: Nakladatel'stvo Pravda.

LEŠKO, V. (2010): Heidegger a dejiny filozofie. Filozofia, 65 (2), 110 - 119.

LEŠKO, V. (2013): Heidegger a grécki myslitelia. Filozofia, 68 (3), $194-204$.

LEŠKO, V. (2015): Patočka, Heidegger a otázka bytia. Filozofia, 70 (6), 429 - 439.

LEŠKO, V. - STOJKA, R. a kol. (2016): Heidegger, metafyzika a Gréci. Košice: Vydavatel'stvo UPJŠ.

LEŠKO, V. (2017a): Heidegger a Parmenides. Filozofia, 72 (5), 357- 370.

LEŠKO, V.: (2017b): Historická správa o nemeckom idealizme. In: Leško, V. - Sobotka, M. a kol. (eds.): Heidegger a novoveká metafyzika. Košice: Vydavatel'stvo UPJŠ.

LEŠKO, V. (2017c): Hegel, negativita a Bytie. In: Leško, V. - Sobotka, M. a kol. (eds.): Heidegger a novoveká metafyzika. Košice: Vydavatel'stvo UPJŠ.

LEŠKO, V. (2017d): Onto-teo-lógia a Hegel. In: Leško, V. - Sobotka, M. a kol. (eds.): Heidegger a novoveká metafyzika. Košice: Vydavatel'stvo UPJŠ.

LEŠKO, V.: (2017e): Hegel a Gréci. In: Leško, V. - Sobotka, M. a kol. (eds.): Heidegger a novoveká metafyzika. Košice: Vydavatel'stvo UPJŠ. 
LEŠKO, V. (2017f): Hegel, koniec metafyziky a otázka bytia. In: Leško, V. - Sobotka, M. a kol. (eds.): Heidegger a novoveká metafyzika. Košice: Vydavatel'stvo UPJŠ.

LEŠKO, V. - MAYEROVÁ, K. a kol. (2018): Heidegger a metafyzika v 20. storoči. Košice: Vydavatel'stvo ŠafárikPress.

LÉVY, B.-H. (2003): Sartrovo století. Prel. M. Novotný. Brno: Host.

SARTRE, J.-P. (1997): Existencializmus a humanizmus. Prel.: J. Švanter. Bratislava: Slovenský spisovatel'.

SARTRE, J.-P. (2006): Bytí a nicota. Prel. O. Kuba. Praha: Oikoymenh.

SIVÁK, J. (2005): Jean-Paul vo svetle Sartrovho storočia. Filozofia, 60 (5), 311 - 333.

THOMSON, I. (2013): Ontotheology. In: Raffoul, F. - Nelson E. S. (eds.): The Bloomsbury Companion to Heidegger. London - New Delhi - New York - Sydney: Bloomsbury.

Táto práca bola podporovaná Agentúrou na podporu výskumu a vývoja na základe Zmluvy č. APVV-14-0706.

\footnotetext{
Vladimír Leško

Katedra filozofie a dejín filozofie

Filozofická fakulta UPJŠ

Moyzesova 9

04001 Košice

Slovenská republika

e-mail: vladimir.lesko@upjs.sk
} 